УДК 61:377.4

\title{
ІНТЕГРАЦІЯ ДОДИПЛОМНОЇ ТА ПІСЛЯДИПЛОМНОЇ ПІДГОТОВКИ ЛІКАРІВ ТА ПРОВІЗОРІВ - ВИМОГА УСПІШНОЇ РЕАЛІЗАЦІЇ РЕФОРМ У СФЕРІ ОХОРОНИ ЗДОРОВ'Я
}

\author{
Р. О. Моісеснко ${ }^{1}$, О. К. Толстанов ${ }^{1}$, В. В. Вороненко ${ }^{1}$, І. І. Фещенко ${ }^{1}$, \\ О. П. Волосовець ${ }^{1}$, Ю. С. П'ятницький ${ }^{1}$, К. В. Баранніков ${ }^{1}$, І. С. Вітенко ${ }^{2}$, \\ I. В. Мельник ${ }^{2}$ \\ ${ }^{1}$ Міністерство охорони здоров'я України, \\ ${ }^{2}$ Центральний методичний кабінет з вищої медичної освіти МОЗ Украӥни
}

\section{INTEGRATION OF PRE-GRADUATE AND POST-GRADUATE TRAINING OF DOCTORS AND PHARMACEUTISTS - DEMAND OF SUCCESSFUL REALIZATION OF REFORMS IN THE PUBLIC HEALTH SPHERE}

\author{
R. O. Moiseyenko ${ }^{1}$, O. K. Tolstanov ${ }^{1}$, V. V. Voronenko ${ }^{1}$, I. I. Feshchenko, \\ O. P. Volosovets ${ }^{1}$, Yu. S. Pyatnytskyi ${ }^{1}$, K. V. Barannikov ${ }^{1}$, I. S. Vitenko ${ }^{2}$, I. V. Melnyk ${ }^{2}$ \\ ${ }^{1}$ Ministry of Public Health of Ukraine, \\ ${ }^{2}$ Central Methodical Cabinet on Higher Medical Education of MPH of Ukraine
}

\begin{abstract}
У статті проаналізовано проблему інтеграції додипломного і післядипломного навчання лікарів та провізорів в ході реформування медичної освіти.
\end{abstract}

The article analyzed the integration problem of pre-graduate and post-graduate education of doctors and pharmacists in the course of medical education reformation.

Вищі навчальні заклади системи МОЗ України беруть активну участь в реалізації реформ системи охорони здоров'я, визначених Президентом України В. Ф. Януковичем, Керуючою радою Комітету з економічних реформ з питань реформування освіти, медицини та житлово-комунального господарства, в тому числі у пілотних регіонах.

Успішне вирішення стратегічних завдань, поставлених керівництвом країни в контексті реформування галузі охорони здоров'я, можливе завдяки поліпшенню якості підготовки медичних спеціалістів, оптимальній організаціїпіслядипломної освіти фахівців у вищих навчальних закладах МОЗ України з урахуванням потреб регіонів у кадровому забезпеченні.

Питання раціонального використання кадрових ресурсів охорони здоров'я потребують комплексного міжвідомчого підходу, вжиття загальнодержавних заходів щодо поліпшення соціального захисту та підняття престижу праці медичного працівника у суспільстві.

(ㄱ Р. О. Моісеєнко, О. К. Толстанов, В. В. Вороненко та ін.
Успішна реалізація реформ у сфері охорони здоров’я можлива за умови забезпечення належного контролю Міністерства охорони здоров'я України над визначенням обсягів та організацією якісної практичної підготовки спеціалістів для потреб галузі охорони здоров'я, післядипломного навчання лікарів та провізорів у вищих навчальних закладах IV рівня акредитації та закладах післядипломної освіти MO3 України.

Саме тому, ще у ході виконання розпорядження Кабінету Міністрів України від 16.11.2011 № 1191-р “Деякі питання управління вищими навчальними закладами" Міністерство охорони здоров'я України інформувало Адміністрацію Президента України, Кабінет Міністрів України, Верховну Раду України, Міністерство освіти і науки, молоді та спорту України про можливість виникнення серйозної загрози реалізації реформ у сфері охорони здоров'я, одним із завдань яких є оптимальне кадрове забезпечення галузі. Це було б особливо критично на етапах організації післядипломної підготовки лікарів на факульте- 
тах підвищення кваліфікації медичних університетів та академій.

Отже, відповідно до розпорядження Кабінету Міністрів України від 30.01.2012 № 75-р "Про передачу в 2012 році деяких бюджетних призначень Міністерству аграрної політики та продовольства i Міністерству охорони здоров'я та внесення змін у додатки 1-3 до розпорядження Кабінету Міністрів України від 16 листопада 2011 р. № 1191” в системі MO3 України збережено дієву мережу галузевих вищих навчальних закладів, які за рівнем кадрового, матеріально-технічного та навчально-методичного забезпечення мають на належному рівні забезпечити науковий супровід реформування системи охорони здоров'я і вирішити питання якісної підготовки медичних та фармацевтичних кадрів.

Підготовка медичних та фармацевтичних спеціалістів на додипломному етапі здійснюється мережею вищих навчальних закладів IV рівня акредитації, яка нараховує 15 медичних університетів (академій), дев' ять 3 яких мають статус національних. Структурними підрозділами 7 вищих навчальних закладів $\epsilon$ також факультети (інститут) післядипломної освіти (підвищення кваліфікаціі). Післядипломне навчання лікарів та провізорів здійснюється відповідно до ліцензій Міністерства освіти і науки, молоді та спорту України на здійснення освітньої діяльності з підвищення кваліфікації лікарів за окремими спеціальностями та напрямами підготовки.

У вищих навчальних закладах IV рівня акредитації MO3 України за державним замовленням навчаються 25 тисяч 332 студенти. За контрактною формою навчається 42 тисячі 598 осіб, громадян України, здійснюється підготовка майже 20 тисяч іноземних громадян 3124 країн світу (студентів - 18410 , клінічних ординаторів - 1063, аспірантів - 126, магістрантів - 165), що складає третину від усіх іноземних громадян, які навчаються в Україні.

Науково-педагогічний процес здійснюють 12788 викладачів, з них 15,7 \% - доктори наук (професори), $57,9 \%$ - кандидати наук (доценти, старші наукові співробітники), 82 - академіки (члени-кореспонденти) НАН, НАМН України.

В Україні створено також мережу закладів післядипломної освіти, де здійснюється післядипломна підготовка лікарів та провізорів (інтернатура, клінічна ординатура, магістратура, аспірантура, докторантура; підвищення кваліфікації-спеціалізація, тематичне удосконалення, передатестаційні цикли, курси інформації та стажування). Зазначена підготовка проводиться в трьох закладах післядипломної освіти
MO3 України - Національній (м. Київ), Запорізькій, Харківській державних медичних академіях післядипломної освіти.

Діяльність факультетів післядипломної освіти вищих медичних (фармацевтичного) навчальних закладів IV рівня акредитації зосереджено в основному на підготовці лікарів-інтернів за базовими лікарськими спеціальностями. За високотехнологічними спеціальностями фахівці проходять відповідну підготовку виключно в академіях післядипломної освіти.

На факультетах (інститутах) післядипломної освіти вищих медичних (фармацевтичного) навчальних закладів IV рівня акредитації та у закладах післядипломної освіти МОЗ України за державним замовленням навчається 7218 лікарів (провізорів)-інтернів, у 2011 році на циклах спеціалізації, тематичного удосконалення та передатестаційних циклах підготовлено 68839 осіб.

План державного замовлення на підготовку спеціалістів до вищих навчальних закладів MO3 України 2011 року виконаний в повному обсязі, зараховано на перший курс до вищих навчальних закладів МO3 4588 лікарів та провізорів, за цільовим направленням для сільської місцевості зараховано 1077 осіб.

3 метою пріоритетного укомплектування центрів первинної медико-санітарної допомоги спеціалістами 3 фаху “Загальна практика - сімейна медицина" в 2012 році планується збільшити план прийому студентів для навчання за спеціальністю "Лікувальна справа" до 3788 осіб (у 2011 році - 2888 осіб), залишаться без змін обсяги прийому студентів за спеціальністю "Педіатрія" - 1000 осіб (як і минулого року), натомість буде зменшено обсяг прийому за спеціальністю “Медико-профілактична справа”, що обумовлено реорганізацією Державної санітарно-епідеміологічної служби України.

План цільового набору сільської молоді до вищих медичних навчальних закладів IV рівня акредитації у 2012 році буде збільшено до 1282 осіб (2011 року він становив 1125 осіб).

3 метою зменшення кадрового дефіциту, який склався в галузі, впроваджено програми цільової підготовки та підвищення кваліфікації лікарів відповідно до потреб регіонів за рахунок коштів місцевих бюджетів на підставі укладання спільних угод між вищими навчальними закладами та регіональними управліннями охорони здоров'я (наказ МОЗ України від 11.11.2011 № 782 "Про впровадження Рішення наради ректорів вищих медичних (фармацевтичного) навчальних закладів IV рівня акредитації та закладів післядипломної освіти МОЗ України “Підсум- 
ки проведення вступної кампанії до вищих навчальних закладів МО3 України у 2011 році. Актуальні питання поліпшення якості та організації підготовки медичних та фармацевтичних спеціалістів” від 11.10.2011". Так, між Національним медичним університетом імені О. О. Богомольця та Київською міською державною адміністрацією укладено угоду на цільову підготовку для м. Києва 140 спеціалістів за спеціальністю "Загальна практика - сімейна медицина” за кошти міського бюджету.

3 метою поліпшення якості та організації підготовки медичних та фармацевтичних спеціалістів Міністерством затверджено та впроваджено в практичну діяльність вищих навчальних закладів та закладів післядипломної освіти МОЗ України наскрізну Програму практичної підготовки лікарів загальної практики - сімейної медицини на додипломному та післядипломному етапах.

Міністерством затверджено Орієнтовний план підготовки та підвищення кваліфікації кадрів для Кіровоградського обласного перинатального центру, План підготовки та підвищення кваліфікації кадрів з метою реалізації національного проекту "Нове життя" для перинатальних центрів АР Крим, Дніпропетровської, Донецької, Житомирської, Одеської, Тернопільської, Харківської областей, які затверджені МО3 України 16.08.2011, План підготовки та підвищення кваліфікації кадрів з метою реалізації Національного проекту "Нове життя” для перинатальних центрів III рівня у 2012 році, затверджений МОЗ України 23.03.2012.

3 метою якісного забезпечення первинної ланки у пілотних регіонах на факультетах післядипломної освіти Вінницького, Донецького національних медичних університетів, Дніпропетровської державної медичної академії, Національного медичного університету імені О. О. Богомольця та Національної медичної академії післядипломної освіти ім. П. Л. Шупика МО3 України затверджено Уточнений перспективний План підготовки кадрів для реформ у сфері медицини у пілотних регіонах та Перспективний план підготовки та перепідготовки лікарів за спеціальністю “Загальна практика - сімейна медицина” на період до 2015 року для забезпечення надання первинної медикосанітарної допомоги в інших областях України.

З метою поліпшення організації підготовки та підвищення кваліфікації лікарів станцій швидкої медичної допомоги з медицини невідкладних станів у пілотних регіонах наказом МОЗ від 17.08.11 № 519 ректорам вищих навчальних закладів MO3 та закладів післядипломної освіти доручено привести кількість циклів спеціалізації, тематичного удосконалення та передатестаційних циклів з фаху “Медицина невідкладних станів” у 2011-2015 роках у відповідність до потреби, визначеної управліннями охорони здоров'я.

MO3 України також розроблено заходи щодо посилення ролі наставництва на робочих місцях в професійній підготовці молодих спеціалістів-лікарів (провізорів), молодших спеціалістів 3 вищою медичною освітою та професіоналів з вищою немедичною освітою, які працюють в системі охорони здоров’я.

Вищі навчальні заклади беруть активну участь в науковому супроводі ходу реформування системи охорони здоров'я. Створено науково-експертну раду Міністерства охорони здоров'я України з питань оцінки реформ в охороні здоров'я. Так, Національний медичний університет імені О. О. Богомольця передбачає виконання таких наукових розробок: “Обгрунтування системи механізмів впровадження інноваційних технологій в первинну медико-санітарну допомогу в Україні”, “Обгрунтування методологічних засад моніторингу та оцінка ефективності реалізації реформ в системі охорони здоров'я'. Національна академія післядипломної освіти імені П. Л. Шупика пропонує розробити засади для створення єдиної державної системи інформаційного забезпечення закладів охорони здоров'я.

Починаючи з 2012 року, на факультетах вищих навчальних закладів IV рівня акредитації та у закладах післядипломної освіти запроваджено цикли спеціалізації з фаху “Загальна практика - сімейна медицина” для перепідготовки (підвищення кваліфікації) лікарівспеціалістів реорганізованих закладів охорони здоров'я (лікарів-педіатрів дільничних та лікарів-терапевтів дільничних), які працевлаштовуватимуться на посади лікарів з фаху “Загальна практика - сімейна медицина”, за затвердженою MO3 України програмою за очно-заочною формою навчання з використанням дистанційних методів підготовки, в тому числі через мережу Інтернет. Відповідно до наказу МО3 України від 07.02.2012 № 90 “Про внесення зміни до наказу МО3 України від 07.12.98 № 346” тривалість очного циклу спеціалізації для зазначеного континенту осіб скорочено $з$ шести до чотирьох місяців, два місяці навчання лікарів-спеціалістів здійснюватимуться без відриву від виробництва (заочно) з використанням дистанційних методів навчання, в тому числі через мережу Інтернет. Загальна тривалість очного та заочного циклів навчання становитиме шість місяців. Програму навчання направлено до вищих медичних навчальних закладів IV рівня акредитації та закладів післядипломної освіти. 
На виконання наказу МОЗ України від 03.12.2010 № 1074 “Про заходи МО3 України щодо удосконалення підготовки лікарів” при Міністерстві створено Координаційну науково-методичну раду з вищої медичної освіти. Відповідно до наказу МОЗ України від 27.04.2011 № 238 основними завданнями Координаційної науково-методичної ради $з$ вищої медичної освіти $\epsilon$ забезпечення координації роботи вищих медичних (фармацевтичного) навчальних закладів, спрямованої на реалізацію державної політики у галузі медичної освіти, зокрема з удосконалення змісту навчання, поліпшення якості медичної освіти та іiї інтеграції в європейське і світове співтовариство, втілення загальноєвропейських стандартів та рекомендацій Світової Федерації медичної освіти.

Питання організації післядипломної підготовки лікарів на факультетах (в інститутах) післядипломної освіти вищих навчальних закладів IV рівня акредитації та у закладах післядипломної освіти MO3 України відповідно до вимог реформування системи охорони здоров'я перебувають на постійному контролі Уряду, Колегії МОЗ України та керівництва МО3 України.

Так, Рішенням Колегії МОЗ України від 17.11.2011 Міністру охорони здоров'я АР Крим, начальникам управлінь (головних управлінь) охорони здоров'я обласних, Київської та Севастопольської міських державних адміністрацій доручено забезпечити першочергове проходження лікарями центрів первинної медико-санітарної допомоги циклів тематичного удосконалення з актуальних питань за профілем практичної діяльності не менше одного разу у міжатестаційний період.

Національному фармацевтичному університету та Національній медичній академії післядипломної освіти доручено забезпечити виконання Концепції розвитку фармацевтичного сектора галузі охорони здоров'я на 2011-2020 роки щодо запровадження системи віртуального та дистанційного навчання відповідно до тенденцій розвитку фармацевтичної науки.

Відповідно до Рішення засідання координаційної науково-методичної ради 3 післядипломної освіти MO3 України, затвердженого першим заступником Міністра охорони здоров'я України Р. О. Моісеєнко 22.02.2012, Міністру охорони здоров'я АР Крим, начальникам управлінь (головних управлінь) охорони здоров'я обласних, Київської та Севастопольської міських державних адміністрацій доручено посилити контроль за підготовкою лікарів зі спеціальності “Загальна практика - сімейна медицина" шляхом забезпечення систематичного проходження ними циклів тематичного удосконалення з актуальних питань акушерства та гінекології, педіатрії, терапії, хірургії у міжатестаційні періоди.

Рішенням Колегії МО3 України від 22.12.2011 Національній медичній академії післядипломної освіти доручено вжити заходів щодо розширення можливостей для отримання громадянами України другої вищої освіти за освітньо-кваліфікаційним рівнем "магістр" за напрямами підготовки "економіка" та “право” для сфери охорони здоров'я на базі академії та Соломонового університету, організувати проведення дводенного навчального семінару щодо актуальних питань реформування системи охорони здоров'я для Міністра охорони здоров'я АР Крим, начальників управлінь (головних управлінь) охорони здоров'я обласних, Київської та Севастопольської міських державних адміністрацій.

На виконання Постанови Верховної Ради України "Про рекомендації парламентських слухань на тему "Про сучасний стан та перспективи розвитку фармацевтичної галузі України” від 06.10.2011 № 3901VI керівникам територіальних органів Державної служби з лікарських засобів та ректорам вищих навчальних закладів IV рівня акредитації МОЗ України доручено вжити заходів щодо забезпечення спільно 3 обласними (міськими) органами місцевого самоврядування цільової підготовки та підвищення кваліфікації провізорів за кошти місцевих бюджетів для потреб фармацевтичної галузі у регіонах.

На виконання Рішення Комітету Верховної Ради України з питань охорони здоров’я від 11.01.2012 № 109 ректорам вищих навчальних закладів IV рівня акредитації та закладів післядипломної освіти було запропоновано продовжити виконання наказу МO3 України від 27.11.2008 № 687 “Про покращання виховної роботи у вищих медичних та фармацевтичних навчальних закладах I-IV рівнів акредитації, закладах післядипломної освіти, науково-дослідних установах і закладах охорони здоров'я" щодо сприяння волонтерському руху задля збереження здоров'я населення України.

На постійному контролі Кабінету Міністрів України перебуває питання забезпечення підвищення кваліфікації лікарів та медсестер для роботи на позитронно-емісійних томографах.

На виконання розпорядження Кабінету Міністрів України від 21.09.2011 № 1036-р “Про затвердження плану заходів щодо забезпечення розвитку освіти у сфері інформаційних технологій на період до 2013 року”, розпорядження Кабінету Міністрів України 
від 27.08.2010 № 1728-р “Про затвердження плану заходів щодо розвитку вищої освіти на період до 2015 року" у вищих навчальних закладах IV рівня акредитації та закладах післядипломної освіти МОЗ України продовжувалась робота щодо впровадження в практику навчального процесу новітніх інформаційних та телекомунікаційних технологій, дистанційної форми навчання тощо. Окрім Центру дистанційної освіти Національної медичної академії післядипломної освіти ім. П. Л. Шупика, який здійснює методичне керівництво за діяльністю вищих навчальних закладів в контексті впровадження та технічного забезпечення дистанційної освіти, в усіх вищих навчальних закладах МОЗ створені науково-практичні лабораторії з дистанційної освіти та новітніх технологій, які мають активізувати свою діяльність.
Отже, ті завдання, які стоять перед вищою медичною школою та наукою в ході реформ системи охорони здоров'я, можуть бути вирішені за умови подальшого збереження існуючої мережі вищих медичних (фармацевтичних) навчальних закладів IV рівня акредитації та закладів післядипломної освіти в сфері підпорядкування МО3, організаційної інтеграції додипломної та післядипломної підготовки лікарів та провізорів, налагодження дієвої співпраці вищих медичних навчальних закладів з МОЗ АР Крим, управліннями (головними) управліннями охорони здоров'я обласних, Київської та Севастопольської міських державних адміністрацій, лікувально-профілактичними установами, на базі яких здійснюється клінічна підготовка лікарів, законодавчого врегулювання різних аспектів системи вищої освіти. 